\title{
A PESTLE Analysis of Biofuels Energy Industry in Europe
}

\author{
Spyridon Achinas ${ }^{1, *}$, Johan Horjus ${ }^{1}$, Vasileios Achinas ${ }^{2}$ and Gerrit Jan Willem Euverink ${ }^{1}$ (D) \\ 1 Faculty of Science and Engineering, University of Groningen, 9747 AG Groningen, The Netherland; \\ j.s.horjus.1@student.rug.nl (J.H.); g.j.w.euverink@rug.nl (G.J.W.E.) \\ 2 Institute for Life Science and Technology, Hanze University of Applied Sciences, Zernikeplein 11, \\ 9747 AS Groningen, The Netherlands; v.achinas@st.hanze.nl \\ * Correspondence: s.achinas@rug.nl
}

Received: 26 September 2019; Accepted: 24 October 2019; Published: 28 October 2019

\begin{abstract}
Biofuels production is expected to be an intrinsic confluence to the renewable energy sector in the coming years under the European regulations for renewable energy. Key standpoints of the biofuels promotions are the reduction of national carbon emissions and rural deployment. Despite jubilant outlook of biofuels for sustainable development, research efforts still tend to link the biofuel industry and regional growth. The aim of this study is to explore and review the biofuels industry through a socio-political, techno-economic, legal and environmental (PESTLE) analysis approach, and discuss the interrelation between technological facets and sustainable deployment.
\end{abstract}

Keywords: renewable fuel standard; biofuel industry; rural development; sustainable deployment

\section{Introduction}

The drive to switch to an alternative transportation fuel is to reduce the dependency on oil and decrease the pressure on the environment [1-8]. The targets set in the RED by the European Commission are to support the development of biofuels [9-14]. Most of the legislations that are developed to achieve these targets are based on life-cycle assessments which often only account for greenhouse gas emissions (GHG) [15-17]. Several other limitations regarding the sustainability of the production, including the competition of feedstock cultivation with the food industry, create difficulties to achieve the short-term production goals of biofuels set by the European Commission [18-23]. This results in the need to develop standard production practices as well as licensing and certification of biofuel manufacture, so that all relevant environmental and social impacts can be regarded [24-27]. To create such production standards, the governing organizations, which are the European Commission and the governments in Europe, need to understand the production processes and its impact on sustainability. Even when policies directed towards a more sustainable production are in place, the production companies need to understand how to adhere to the legislation. They will need to increase their research and development into the energy production processes [28-31].

The biofuel industry is still developing, as the consumption of all biofuels in the European Union (EU) increased with 8\% from 2016 to 2017 [32]. In the EU, the renewable energy directive (RED) is created as a policy to support the production and development of these renewable energies [13]. Especially for the transportation sector, the objective for all the EU countries is to have $10 \%$ renewable energies in 2020 [33]. Biofuels are considered as the key product to achieve this target and further criteria regarding their sustainability are developed [34]. Several literature sources stress the importance of understanding the role of biofuels in the possible reductions in life-cycle greenhouse gas (GHG) emissions that can be achieved with respect to fossil fuels to inform policy development and the decisions regarding the best fuel types [35]. This research will take this broader by analyzing the sustainability factors which 
influence the biofuel industry, and relates this to the biofuel characteristics, including the type of fuel, feedstock, and conversion process. In addition to the support for policy development, the research and discussion of the biofuel characteristics have the intent to provide a foundation for the directives that companies are going to take to adhere to the policies. Sustainability assessment of biofuels production from biomass and biowaste is an important prerequisite for informed and sound decision-making. However, life-cycle analysis (LCA) is still constrained by the difficulty of pointing out the most relevant impact factors. To underwrite the mighty risks confronted by the industrial efforts are pointed out in order to bestow the optimal use of energy and resources. Identification of key stakeholders and deployment of the political, economic, social, technological, legal, and environmental aspects from the updated literature, reports, and guidelines are intrinsic to achieve a thorough understanding of the complex landscape of biofuel industry. The contribution of the biofuel industry to sustainable development is key in the growing biofuel industry that is driven by the renewable energy targets of the European Union. Both policymakers and production companies require an understanding of the relation between biofuel production characteristics and the sustainability of the industry to be able to support sustainable development [36-44]. The objective of this report is to (1) summarise the key interdependencies in the biofuel industry based on PESTLE analysis and (2) create a review in which the key biofuel production characteristics are correlated with the sustainability factors that are affected by the biofuel industry. Hereafter, the different aspects influencing the sustainability of bioethanol, biodiesel, and biomethane industry are determined and these are allocated to the economic, environmental, socioecological, and geopolitical facets [45-55]. Finally, both quantitative and qualitative data are assessed to correlate both aspects and determine the strengths and weaknesses of the different biofuel characteristics. The analysis of the production processes shows that the key factors to be considered are both the choice of feedstock and the conversion technology that is applied. A key distinction in the feedstock is the cultivation of crops dedicated to biofuel production or using wastes and residues from other sectors as feedstock. Regarding the conversion processes, all three biofuels can be produced via a biochemical or the thermochemical pathway [56-58]. Both feedstock and production process influence the economic sustainability, showing that crop-based biofuels have a high feedstock cost and low capital cost, compared to the relatively low cost for feedstock and high capital cost for the biofuels from lignocellulosic biomass, wastes, and residues [59-76]. Moreover, the latter are also significantly more environmental and socioecological sustainable compared to the crop feedstock that imposes the impacts of land use and land-use change. Geopolitically, the EU supports the EU biofuel producers by protecting the market from lower prices introduced by imported biofuels. The political support for the more extensive development that is required for the biofuels from lignocellulosic biomass, wastes, and residues is starting to increase, but significant differences are detected among EU countries due to a lack of budget and existing infrastructure. Finally, a small discussion about the future of the biofuel industry is provided, considering the future use of fossil fuel and the development of other renewable alternatives such as hydrogen fuel and electric vehicles [77-79].

It is important to stress that this research will not be directed towards one answer, but rather assesses collected knowledge to provide an overview of the interrelations between the production industry and the sustainability and highlight the apparent distinctions and characteristics. This research correlates the different biofuel production characteristics with the sustainability of the biofuel industry in the context of economic, environmental, socioecological, and geopolitical facets. Hereafter, both subjects will be combined with a thorough assessment and discussion of literature and data obtained from literature to create a correlation. Finally, an outlook will be provided to evaluate possible external influences on the biofuel industry in the future. 


\section{Materials and Methods}

\subsection{Problem Context}

The problem context indicates a research interest in the sustainability of the biofuel production processes. Understanding the interrelation between the two is essential for the future of biofuels since it is its sustainability, both economically and environmentally, which has created greater attention for biofuels among the many other alternative energy sources [80-90]. Since the possibilities in production processes depend on the type of feedstock used in the processes, several feedstocks are taken into account [91-94]. To further limit the number of different production processes, only the three biofuels will be considered: Bioethanol, biodiesel, and biomethane.

The scope of the sustainability aspects is discussed by specifying the key issues of the sustainable development of biofuels which are divided into four subsections: Economic, environmental, socioecological, and geopolitical. The first three sections combined provide the sustainability factors involved with biofuel production as found in literature and the subdivision is supported by the framework of Mangoyana et al. (2013) [95]. Since the social factor introduced in the framework includes aspects such as land use and biodiversity, the term 'socioecological' is deemed more suited. Finally, the geopolitical substratum is added to consider the effect of governmental support and their policies on biofuel development. The support still differs between countries in the EU due to their own individual interests [14]. Moreover, the independence of energy supply is a driving force for adopting biofuels in the EU.

The factors influencing the economic sustainability of the biofuel industry are all related to the economic feasibility of production [96]. The key factor is the start of new biofuel production companies, or the extension of current production lines, for the development of the biofuel industry in terms of its market size with respect to other fuels. Hence, the focus will be on the choices in production processes, including the type of biofuel and feedstock, and its relation to the sustainability facets. The environmental facet includes the GHG emission of the process to the discussion of sustainability. The emissions of fossil fuels are an important driving force for the development of biofuels, which are expected to have a lower net GHG emission due to the plant feedstock [97-101]. In addition, there are the factors that have both an impact on the environment, the society, and the quality of life of the individual inside that society, that are covered in the socioecological facet [102].

The inputs of the system are the commercially applied production processes of bioethanol, biodiesel, and biomethane together with the factors that determine the economic, environmental, socioecological, and geopolitical sustainability of the production processes that will be determined and will be discussed in the methodology of this research. It is projected to deliver insights into the performance of the different production technologies, feedstocks, and final biofuel product with respect to the sustainability of the biofuel industry. First, the different possibilities in the production of bioethanol, biodiesel, and biomethane have to be determined. Thereafter, it has to be determined how different biofuel production characteristics contribute to the sustainability facets described in the scope of the research and summarized in the economic, environmental, socioecological, and geopolitical facets.

The main sources of information will be review articles on biofuel technologies to provide an overview of the existing technologies. Moreover, technical reports of different associations focused on renewable energies and fuels will be used to obtain data on the recent commercial production. Quantitative data regarding, among others, production cost and GHG emission of these reports will then be combined with the research articles obtained from databases. Search terms including 'biofuel production process', 'bioethanol/biodiesel/biomethane production', 'feedstock biofuels', 'biomass conversion', 'biofuel conversion technology', 'production cost biofuels', 'policies biofuel production', 'water use biofuel', 'life cycle analysis biofuel', 'politics biofuel', and 'land use biofuel', will be used to obtain the articles from the literature database.

From the analysis of the different feedstock types and conversion processes for bioethanol, biodiesel, and biomethane, a simplified overview of the production pathways is provided in Figure 1. Overall, 
the feedstocks can be subdivided in the first-generation complete crops and the second-generation, or advanced, biofuels from residues, wastes, and lignocellulosic biomass.

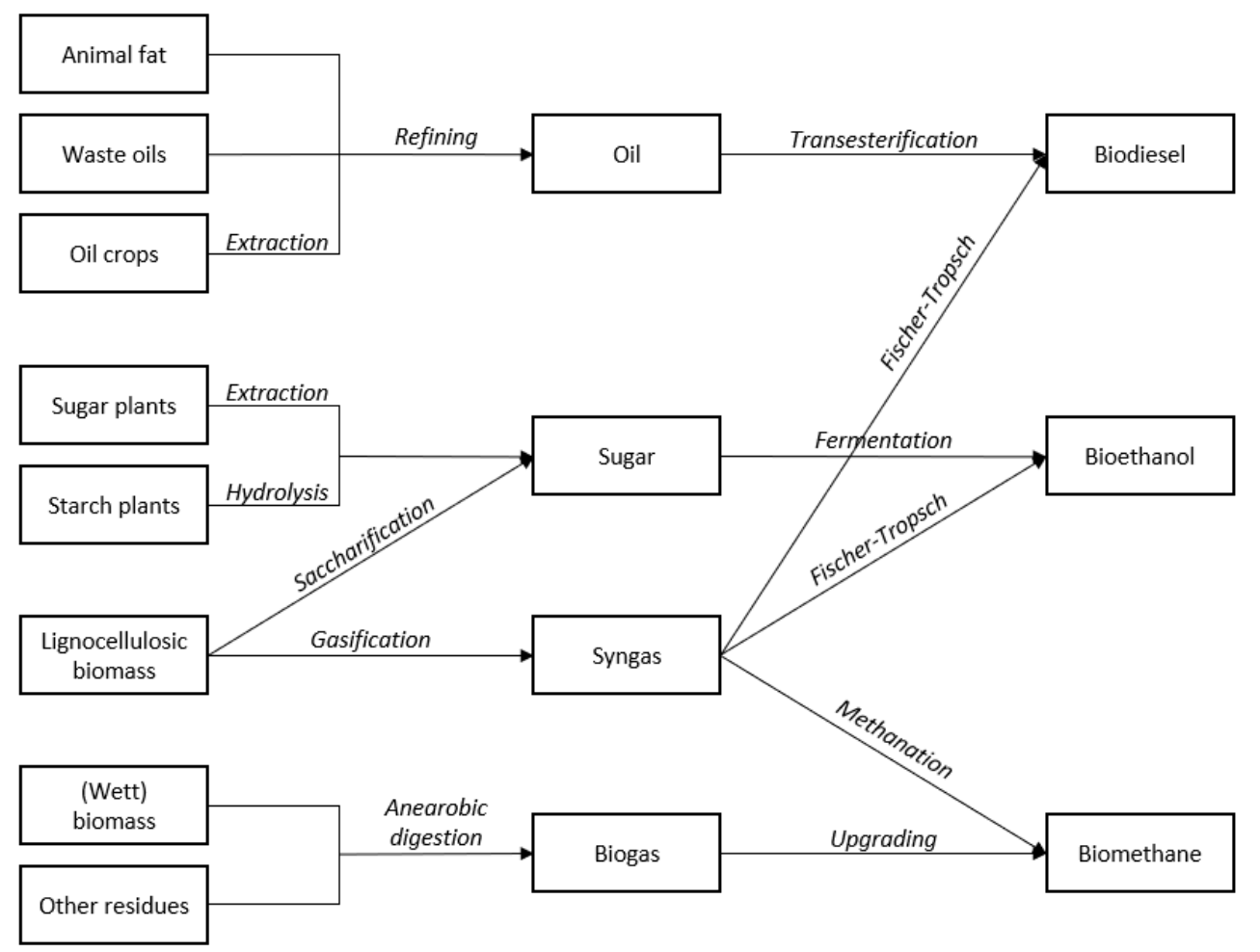

Figure 1. The different production pathways from feedstock to biofuel, self-constructed. The arrows indicate conversion processes, and the rectangles indicate the inputs and outputs of those conversion processes.

The factors from the sustainability facets that are directly affected by the biofuel industry will be determined by a PESTLE analysis. The final deliverable, the interrelation between the biofuel production characteristics, and the described sustainability factors, will be determined by an assessment of both qualitative and quantitative data obtained using the described literature research. In addition to the definite results, a discussion of the results will be incorporated to address and include the complexity of the biofuel industry and the linkages between the different sustainability facets.

\subsection{PESTLE Analysis}

The PESTLE analysis will be used to evaluate the external influences on the biofuel industry. It originates from marketing analysis, but these external influences on the industry will be used to determine the factors influencing the long-term sustainability of the industry. PESTLE stands for Political, Economic, Social, Technological, Legal, and Environmental. It provides a broad view of the complete environment of the biofuel industry. The analysis will determine the factors for the economic, environmental, socioecological, and geopolitical sustainability facets. It provides the framework for the correlation with the production technologies to determine the strength and weaknesses of the different production pathways.

\subsubsection{Political and Legal}

The political and legal aspects of the biofuel industry in the EU are driven by directives developed by the European Commission such as the RED. Each country has developed its own legal framework to support the national biofuel industry in achieving the target of $10 \%$ renewable transportation fuel by 2020 [12]. Recently, the RED has developed in recognizing the effect of indirect land-use change [33,34]. 
Furthermore, the competitiveness of biofuels in industrialized countries is driven by the subsidies and import tariffs in place. These tools create a significant barrier to international trade from the EU to other countries and therefore create a captive market for the national biofuel producers in the EU [103]. Politically, there are several factors impacting the national biofuel market, including employment laws and tax policies. However, to understand the overall political and legal impact on the EU biofuel market, the focus is on the differences in support policies for the biofuel development for each country. The support system for each biofuel significantly impacts the long-term sustainability of the biofuels.

\subsubsection{Economical}

As mentioned, the political aspect influences the economics of the biofuel industry by providing subsidies and creating import tariffs to protect and support the market. The biofuel industry, like any other industry, will be affected by changes in the economic environment which are, among others, tax, interest and exchange rates. However, specifically for the long-term sustainability of the biofuel market, the factor that will be addressed is the demand and supply of biofuel. The production cost of the different biofuels relates to the price, which affects the demand and therefore influences the supply. This circle is impacted by political influences, social behavior, and the development of technology. Hence, the application of PESTLE analysis to obtain a complete overview of the long-term sustainability of the biofuel industry.

As a replacer of fossil fuels, the competitiveness of biofuels does not only depend on its own production cost but even more so on the price of fossil fuels. Moreover, the current subsidies largely influence the competitiveness of the biofuel production cost. Biodiesel, bioethanol, and biomethane all have their own economic sustainability, influenced by factors including the feedstock, the type of conversion technologies, and the number of required processing steps. First, the cost of buying and cultivating feedstock differs depending on the type. Moreover, each feedstock has its own productivity influencing the overall cost per unit or volume of the feedstock [95]. Depending on the feedstock and the type of biofuel, there is a different conversion technology to produce the biofuel. Each conversion type has its own cost to implement and execute in a production process. However, the cost will develop with time, influenced by the learning and scaling effects [104]. In addition, the type of feedstock influences the number of production steps, since some types require pre-treatment or purification processes.

\subsubsection{Technological}

First, the technological aspect covers the technological developments and innovations in the industry [105-107]. The scope of this research on commercially available production technologies limits the effect of innovation on long-term sustainability. It is, however, important to notice that the development of the third generation biofuels, produced from algae, is a future development that could render the biofuels considered in this research relatively less sustainable [108-115].

Important to consider, is the overall development of the fuel and transportation industry, as electrical transportations vehicles become more important. The consideration of starting a biofuel production company at this moment of time should include the expected life cycle of the industry. If the electric vehicle industry developments increase significantly, the investments in biofuels could be unprofitable because of a decrease in demand. The technological influence on the biofuel industry highlights the importance of the expected demand and raises the question: Is the expected time until the demand of biofuel that will decrease due to other technologies long enough to be a profitable investment? On the other hand, the ability to convert the production process or use it for other applications will influence the expected lifetime of the investment.

\subsubsection{Social}

The influence of the social aspect of the biofuel industry relates to social changes and social stability. The common examples are the competition with the food supply and the cost of biofuels [95]. Moreover, water use in the biofuel industry will impact social stability. Water is already a scarce 
resource in many parts of the world, and the continuing development of the biofuel industry can add to the existing pressures [116].

A significant amount of the feedstock discussed in the previous chapter are also agricultural products used in food production, for example, corn and sugar beet. Therefore, the development of biofuel production has a significant impact on the world's agricultural market and food security [117]. Moreover, cultivation of the biofuel feedstock competes directly for land with other food crops such as coffee beans or rice. The feedstock that is also used for food and feed production including corn, wheat, sugar cane, soybean, rapeseed, and sunflowers are denoted as the first-generation feedstock. On the other hand, the second-generation feedstock, which includes lignocellulosic biomass and waste oils, do more increasingly support the co-existence of biofuel and food production [1].

Due to the existing pressure on water, the water consumption of the cultivation and conversion processes of the biofuels impact the overall sustainability of the production processes [116]. The different feedstocks will be analyzed on the use of water in the harvesting techniques. Moreover, the relative water consumption of the production process for each biofuel and feedstock will influence its impact on water scarcity. The ability to recycle the water streams in the process, thus reducing the net water use, is a significant factor that affects the performance of the process regarding water use.

\subsubsection{Environmental}

In the case of the biofuel industry, the environmental facet is extremely important since the reduction of the GHG emission is one of the key components in the sustainable development and one of the factors driving the transition to biofuels [118]. Moreover, it is important to note the interrelation between the social and the environmental aspects influencing the biofuel industry. This research defined the socioecological facet to summarize the factors that influence both aspects, including water scarcity and food competition. It also includes the aspect of land use for the cultivation of feedstock that has a large impact on the environment and social factors of the biofuel industry. Several life cycle assessments (LCA) obtained from literature, describe the improvement in GHG emission for different types of biofuels. Important are the different aspects influencing the GHG emission of biofuel production. The aspects include the type and management of the feedstock and the conversion technologies [119]. However, the results may also differ depending on the system boundaries of the LCA. Hence, the importance of an overall assessment of different sources in the following analysis. The general assumption in the LCA studies, regarding the GHG emission, is that $\mathrm{CO}_{2}$ emissions from biomass combustion are climate-neutral due to the biomass absorption of $\mathrm{CO}_{2}$ during growing [120]. Hence, the GHGs will depend more on the production processes surrounding biomass combustion.

The aspect of land-use incorporates the essential difference between the restoration of degraded farmlands or removing forests for biofuels [121]. The term indirect land-use change (ILUC) describes the change of natural environments to croplands to grow crops that replace the feedstock used for biofuels. Essentially, it is the effect of competing with the same resources as the food industry. The ILUC leads not only to a loss in biodiversity but also increases the GHG emission and impacts the prices of food [122]. The potential GHG savings are important for biofuel development, but they are reduced due to land-use change by, for example, deforestation. The exact land-use effects depend on the type of land that will be used and if deforestation is avoided [14]. These motives are hard to predict, therefore this study will take the land requirement of the feedstock, feedstock productivity, and the ability to grow on more degraded land as key factors influencing the land use [14]. The conversion of waste streams to biofuels is an important example of a feedstock that minimizes the land use. The interrelation between the land use and the environmental sustainability is recognized, but it is considered as socio-ecological due to its causal relationship with feedstock cultivation and its effect on the biodiversity, food competition, and water use.

Finally, biodiversity is also affected by the increase in crop cultivation due to biofuel development [123]. Biodiversity is supported by an environment with multiple crop species, while biofuel production yields are increased by the reduction of feedstock types that are cultivated 
in one area. The water use of the biofuel production can also be argued as an environmental aspect, hence the allocation to the socio-ecological facet.

\subsubsection{Overview of Sustainability Framework}

The results of the PESTLE analysis are summarized in Table 1. The collected factors will be correlated to the different production technologies, depending on the biofuel, feedstock, and conversion technology.

Table 1. The results of the PESTLE analysis as obtained are summarized per subcategory.

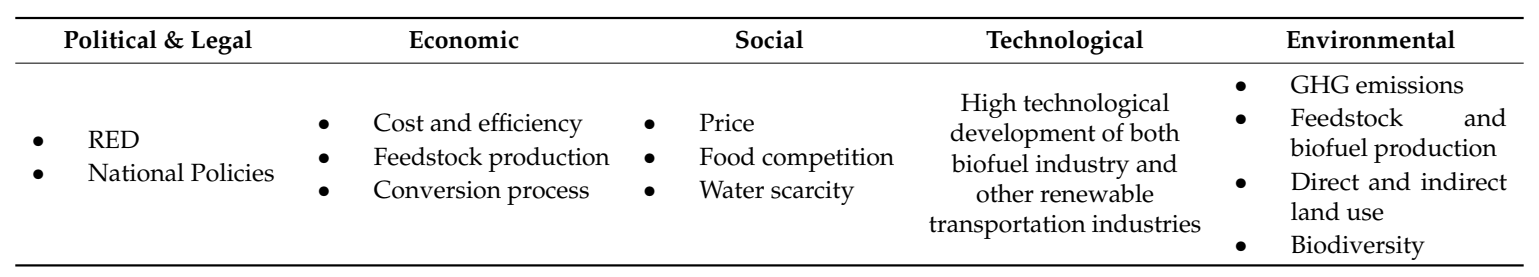

The different factors from the PESTLE analysis all affect the long-term sustainability of the biofuel industry. The factors are subdivided into the sustainability facets where both the political and economic factors are directly assigned to the geopolitical and economic sustainability facet, respectively. Socioecological governance comprises the factors of food competition, water scarcity, and biodiversity, all affected by the discussed land-use change phenomena. The GHG emissions are covered in the environmental facet, which emphasizes one of the driving forces of biofuel development.

\section{Correlation between the Production Processes and the Sustainability Framework}

\subsection{Economic Landscape}

First, the distinction of biofuel produced from food crops and biofuel produced from waste and residues streams is often used in literature and is referred to as first- and second-generation biofuel, respectively. Regardless of the large variety in the production cost of biofuel that is influenced by feedstock, conversion process, the scale of the production, and the region, a general trend is determined. The first-generation biofuels have a significantly lower capital cost compared to the second generation. However, the feedstock cost of the first-generation biofuel poses a threat to its viability since it generally represents around $60-90 \%$ of the total production cost [35]. In the long term, the feedstock cost accounts for $30-45 \%$ of the total production cost for biofuels from lignocellulosic biomass. The second-generation biofuels will become competitive as the high capital costs reduce by the development of the relatively new conversion technologies. Nevertheless, the price of oil also impacts the biofuel industry to the extent that an oil price below US $\$ 80$ per barrel will deem the second-generation biofuel uncompetitive with the fossil fuel market for the next 30 years [124].

Due to the high contribution of the feedstock to the total cost of the first-generation biofuel, the crop feedstocks are evaluated on, among other aspects, their efficiency. Table 2 indicates the high potential energy yield of the sugar feedstock compared to the starch feedstock. However, the conversion efficiency strictly dictates the overall productivity of the complete feedstock to the fuel process. It is notable to mention that raw sugarcane is not produced in the EU, it is always imported in the framework of preferential trading relationships. Raw sugarcane is processed in European countries contributing to the biofuel industry. Table 4 shows some results where the bioethanol from sugar crops still is superior considering the overall productivity. The energy productivities indicate a lower efficiency in terms of liters/ha for biodiesel crops production compared to both bioethanol and biomethane. However, the energy in terms of GJ shows more similar values, implying that the energy value of bioethanol in GJ/liters is significantly higher than that of biodiesel. The bioethanol from lignocellulosic biomass, see the cereal straw in Table 4 does not have competitive energy productivity. The overall economic sustainability could, however, profit from the low cost of waste streams as a feedstock [125]. 
Similar conditions apply to the residue feedstock-types used for both biochemical and thermochemical biodiesel. The woody crops and short rotation plants do show competitive energy productivity values of around $90 \mathrm{GJ} / \mathrm{ha}$ for thermochemically produced biodiesel.

Table 2. The yields of possible crop feedstock for biofuels in terms of its weight (tons) and energy (GJ) per hectare of cropland [126-128].

\begin{tabular}{ccc}
\hline Feedstock & Yield (t/ha) & Yield (GJ/ha) \\
\hline Sugar cane & $68.7-70.9$ & 370 \\
Sugar beet & $61.5-68.9$ & $243.7-281$ \\
Maize & $3.9-5.8$ & 61 \\
Wheat & $3.5-7.9$ & $77-119.4$ \\
Rapeseed & $2.2-3.5$ & $74-84.4$ \\
Sunflower seeds & $1.8-2.4$ & 58 \\
Soya beans & $2.8-2.9$ & 56 \\
Woody crops & $11-27$ & $87-239.4$ \\
\hline
\end{tabular}

In terms of availability, the cultivation of crops as a biofuel feedstock is not directly a problem as additional land could be acquired. It does significantly affect other sustainability facets of the industry as will be discussed later this chapter. The non-food crop feedstocks for biofuels including the woody residues used cooking oil, and animal fats also have an application in competing sectors. Nevertheless, it is determined that, as the total amount of these feedstock-types available is significantly larger than the demand from the competing sectors, the feedstock is available in a considerable amount for the biofuel industry. However, the availability of waste and residue streams has its limitations since the dedicate production of that core product for biofuels eliminates practically all benefits of the feedstock, which will be encountered when the demand increases.

Now, the efficiency of feedstock does influence economic competitiveness, but in the end, the cost of the energy source is the most important. Therefore, considering the cost not only with respect to volume but also the energy contribution is key to the sustainability assessment. The trend in firstand second-generation biofuels and the influence of the oil price, as described before, is also visible in Table 3, where the cost is normalized with respect to energy productivity. The values of energy productivity used in the previous study [125], from Table 3, differ from the values stated in Table 4, and these types of values are influenced, among others, by the region of feedstock origin and the weather [128]. However, the key message to extract is that for production of one fuel, the common values to consider are the cost per volume of fuel, whereas for the final consumption it is about the energy that can be extracted from the volume of fuel which will influence the cost assessment. Table 3 shows that the biodiesel produced from waste oil has a competitive production cost that will decrease even further with the development of the technology. The bioethanol from lignocellulosic biomass shows the prospects of the reduction in capital cost that directly creates a competitive production cost in the year 2020. The cost of conversion for the crop feedstock will not change significantly over time as the technology is matured, implying that the increase in production cost is imposed by the expected increase of crop prices [125]. Table 3 also depicts the smaller cost range for lignocellulosic bioethanol and biodiesel from waste oils, which implies that these products are the least sensitive for oil price changes. As the cost of the conversion process is more significant for the second-generation biofuel, the data in Table 5 addresses the different types of cost for both the biochemical and the thermochemical production pathway. 
Table 3. The production cost for different biochemical produced biofuels and feedstock under varying oil price scenarios for both the year 2015 and 2020. The results are adapted from [125]. The total costs are normalized based on the energy density of the biofuel with respect to the energy density of fossil fuel to ensure the comparability of the total cost of the different biofuels.

\begin{tabular}{ccccc}
\hline (Bio-) Fuel & Raw Material & $\begin{array}{c}\text { Crude Oil } \\
\text { Price [€/Barrel] }\end{array}$ & $\begin{array}{c}\text { Total Costs Normalized on Energy } \\
\text { Density (€Cent/L) }\end{array}$ \\
\hline & & & $\mathbf{2 0 1 5}$ & $\mathbf{2 0 2 0}$ \\
\hline Fossil fuel & Crude oil & $50-200$ & $36.5-130.8$ & $36.5-130.8$ \\
Bioethanol & Maize & $50-200$ & $105.6-140.2$ & $110.6-145.3$ \\
Bioethanol & Wheat & $50-200$ & $136.4-186.1$ & $151.3-202.6$ \\
Bioethanol & Lignocellulosic waste material & $50-200$ & $157.3-171.2$ & $81.5-95.4$ \\
Biodiesel & Rapeseed oil & $50-200$ & $117.5-171.4$ & $138.4-192.3$ \\
Biodiesel & Palm oil & $50-200$ & $70.0-121.9$ & $63.7-115.5$ \\
Biodiesel & Waste oil & $50-200$ & $61.8-89.9$ & $45.4-73.6$ \\
\hline
\end{tabular}

Table 4. The yields of the different biofuel types per hectare of crop feedstock in terms of energy (GJ) and volume (liters) expected in the year 2020. The conversion technologies are all biochemical with exception from the thermochemical Fischer-Tropsch (FT) biodiesel. Adapted from [129].

\begin{tabular}{cccc}
\hline Type of Biofuel & Feedstock & $\begin{array}{c}\text { Energy Productivity } \\
\mathbf{2 0 2 0}(\mathrm{GJ} / \mathbf{h a})\end{array}$ & $\begin{array}{c}\text { Energy Productivity } \\
\mathbf{2 0 2 0} \text { (L/ha) }\end{array}$ \\
\hline \multirow{3}{*}{ Bioethanol } & Wheat & 42 & 2000 \\
& Maize & 64 & 3030 \\
& Barley & 38 & 1770 \\
& Sugar beet & 145 & 6840 \\
Biomethane & Sugar cane & 118 & 5570 \\
\hline \multirow{2}{*}{ Biodiesel } & Silage Maize & 123 & 740 \\
& Sunflower oil & 24.5 & 2660 \\
& Palm oil & 88 & 1570 \\
\hline Bioethanol & Rapeseed & 52 & 530 \\
\hline \multirow{2}{*}{ FT Biodiesel } & Soybean & 17 & 710 \\
& Cereal straw & 15 & \\
\hline & Miscanthus \& Switchgrass & 90 & \\
\hline
\end{tabular}

First, a large variation in feedstock price for the biochemical production of biomethane is apparent. The opportunity for biofuels is the low feedstock prices that can be obtained from using waste streams, which will be the type of zero cost feedstock [130]. The range of the production cost for biochemically produced biomethane can thus largely be allocated to the type of feedstock. Therefore, the more advanced and less mature thermochemical processes do show a slightly higher production cost compared to the biomethane after biogas upgrading. For the biochemical produced bioethanol from lignocellulosic biomass, the production cost will be higher as for crop-based bioethanol due to the additional process steps for lignocellulosic biofuels as discussed in the earlier chapter. 
Table 5. Overview of the production cost (range) per unit of energy of both the biochemical (biomethane and bioethanol) and thermochemical (biomethane and biodiesel) for predefined feedstock. The cost of the biochemical conversion of biomethane covers all the different feedstock for anaerobic digestion. Adapted from [130].

\begin{tabular}{|c|c|c|c|c|c|}
\hline $\begin{array}{l}\text { Type of } \\
\text { Biofuel }\end{array}$ & $\begin{array}{l}\text { Conversion } \\
\text { Process }\end{array}$ & Feedstock & $\begin{array}{c}\text { Feedstock } \\
\text { Price }(\boldsymbol{E} / \mathbf{M W h})\end{array}$ & $\begin{array}{l}\text { Production Cost } \\
\text { Range ( }(€ / M W h)\end{array}$ & $\begin{array}{l}\text { Production Cost } \\
\text { Range ( }(€ / G J)\end{array}$ \\
\hline Biomethane & Biochemical & 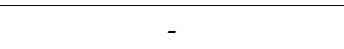 & $0-80$ & $40-120$ & $11-34$ \\
\hline Bioethanol & Biochemical & Cellulosic biomass & $10-13$ & $85-103$ & $24-29$ \\
\hline Biomethane & Thermochemical & Waste and wood biomass & $10-20$ & $56-91$ & $16-25$ \\
\hline Biodiesel & Thermochemical & Wood biomass & $10-20$ & 90-139 & $25-35$ \\
\hline
\end{tabular}

For the overall economic sustainability of the different biofuels, a trend is clear that the expected feedstock cost favors the use of biomass, wastes, and residues. Only considering the feedstock cost, the fuels produced from lignocellulosic biomass: All thermochemical production process for the three biofuels, and the biochemical pathway for bioethanol, and the production from wastes and residues, which include the biochemical production of both biodiesel and biomethane. Hence, the biomethane has the highest number of production possibilities which provide a competitive feedstock cost. Moreover, the biochemical production of biomethane from biogas is a more mature technology, similar to the other biochemical production processes from crop feedstock that show competitive cost figures. However, the capital cost of the second-generation feedstock is expected to become competitive due to the development of the industry. A similar effect needs to apply to the thermochemical production path to support the economic sustainability of the biofuels produced via the syngas pathway from lignocellulosic biomass. To invest in these advanced biofuels in the current circumstance, long-term policy support is the only tool to provide certainty that investors will achieve a return on investment [131]. An extended scope, outside of the biofuel industry, shows that a low oil price could still render all the biofuels less economic sustainable due to the resulting uncompetitive production cost.

For the deployment of biomethane as fuel, the additional cost barrier exists of extending the distribution and fueling infrastructure of gaseous fuels [132]. Here the support, both in realizing and financing, of the national governments is necessary to allow a connection with the natural gas grid system. In addition to the investments required to start a production plant for one of the biofuels, these infrastructure costs for biomethane do affect its economic sustainability but they are essential to ensure demand for the fuel.

\subsection{Environmental Governance}

The GHG emissions will be correlated to the different types of feedstock and the different production processes. A variance in the GHG emission among the feedstock types is especially highlighted by the recent attention to the effect of indirect land-use change imposed by crop feedstock.

A broad overview of the emissions from the supply chain of the biofuels is depicted in Figure 2, distinguishing between the contribution of cultivation, processing, and transport to the total emission of the supply chain [128]. The study used the BioGrace [133] tool for calculations of the different types of emission that are expressed in $\mathrm{CO}_{2}$-equivalents. The data in Figure 2 shows clearly that cultivation of the feedstock, if applicable, contributes on average for at least $50 \%$ to the total supply-chain emissions. Therefore, both biomethane production and biodiesel from waste oils have a superior position by non-agricultural waste streams as feedstock. The agricultural waste stream of lignocellulosic biomass used in the advanced ethanol and FT diesel contributes to the GHG effect by the utilization of fertilizers during cultivation [128]. 
Supply chain emission factors of biofuels

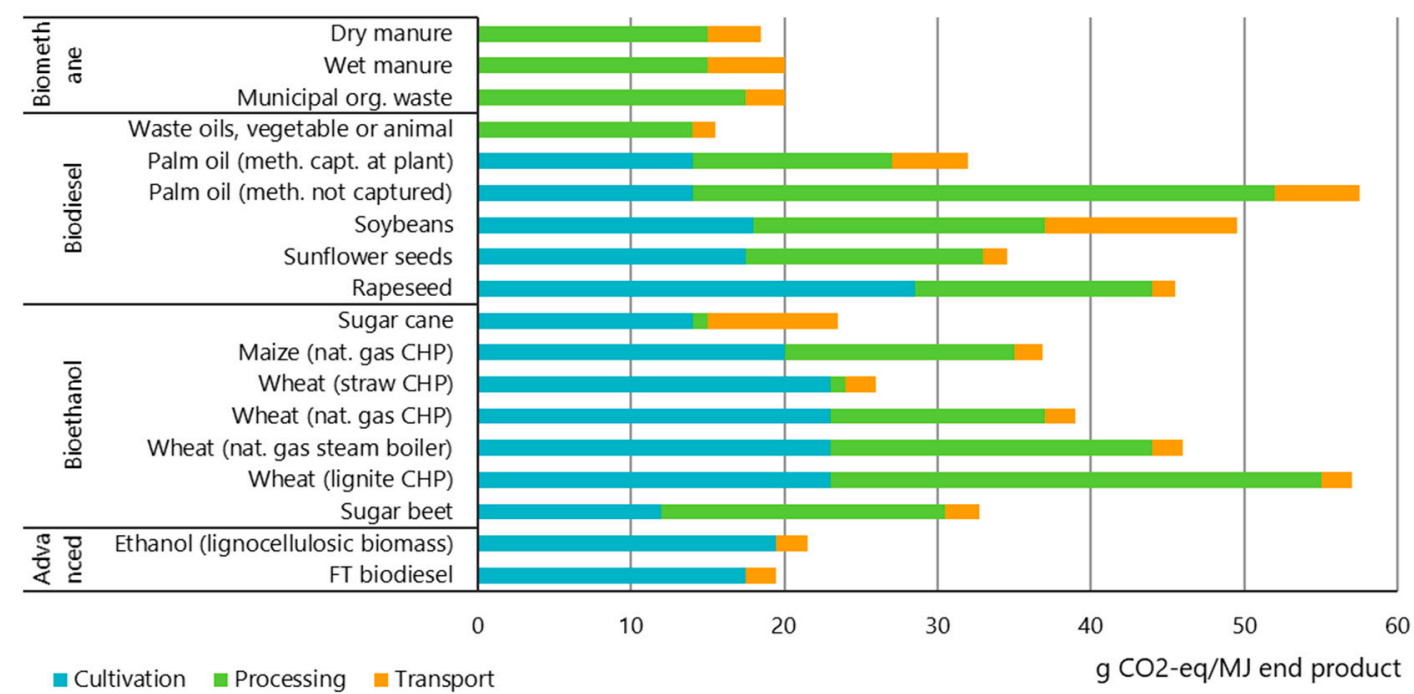

Figure 2. Supply chain emission factors expressed in the equivalent grams of $\mathrm{CO}_{2} / \mathrm{MJ}$ of the end product, adapted from [128]. The results are based on [134] for the advanced biofuels and based on BioGrace [133] for the others, taking co-products into account. All processes are biochemical except for the thermochemical Fischer-Tropsch (FT) biodiesel. The text between parentheses in the ethanol category refers to the feedstock for processing.

The emissions during the conversion processes of the biofuels are influenced by the fossil energy consumption as clearly depicted in the case of lignocellulosic biomass where it is assumed that the conversion energy will be derived from the biomass itself. The same applies to the results depicted for sugar cane, where the conversion emission are calculated under the assumption that energy is produced from the by-product bagasse.

Overall, this discussion of recycling of waste streams in the biofuel processes creates not only the challenge in the analysis of emissions but will also affect production costs. Another example is the case where bagasse can also be used as lignocellulosic biomass for biochemically produced bioethanol or the thermochemical production. However, in this case, the bagasse can be a waste stream of the food industry compared to an internal waste stream as with the utilization of sugar cane. Another possibility one could imagine is the replacement of fossil fuels used in transport and conversion process by biofuels.

For environmental sustainability purely, this implementation would be ideal since it will reduce the emissions of the supply chain. However, considering the economic landscape, it would only weaken the efficiency of a production process since the land use will increase to produce similar amounts of biofuel. Such implementation would thus require the development of policies and production criteria and to a higher extent analysis of emissions imposed by the additional land use. If a fossil system is an alternative to using residues for energy production, the use of food waste for biofuel production can show overall negative GHG emission effect since the loss of energy will be compensated with fossil fuels. This relation will develop on the long-term as sources for the electricity and heat sector will be less pollutive for the environment [135].

Overall the land-use change imposes reduces the environmental sustainability of biofuels produced from food crops compared to alternatives. There is even research that reports a net increase in GHG emission for food crop biofuels imposed by the land use impacts compared to fossil fuels [135]. Table 6 clearly shows the higher land-use emissions for the biodiesel feedstock compared to bioethanol. First of all, a relation is visible between crop productivity and the land-use emission, as less land is required to produce the same amount of energy. This effect benefits the first-generation bioethanol feedstock over the oil crops for biodiesel. Moreover, the land used to grow the crops impacts the 
overall emission. For biodiesel, specifically for palm oil, the emission is a consequence of the high conversion of peatlands into palm cultivation areas [129]. This impact is confirmed by the study of [128], where direct land-use change from grassland is significantly favorable compared to the conversion of forest lands to biofuel croplands. Hence, the negative values for the fast-growing plantation for FT biodiesel, which are particularly grown on marginal lands and thus improve the conditions of the land resulting in an overall reduction of emissions. The land-use emission for biomethane production shows no significant differences with the bioethanol production from crops. The use of agricultural wastes from the food industry could to an extent reduce these emissions since the cultivation is not directly influenced by the biofuel demand.

Table 6. The land use emissions for various feedstock that include both the direct and indirect effects of both land use and land-use change. All conversion processes are biochemical, except the thermochemically produced Fischer-Tropsch (FT) biodiesel. Adapted from [129].

\begin{tabular}{ccc}
\hline Type of Biofuel & Feedstock & Land Use Emission $\left(\mathrm{g} \mathrm{CO}_{\mathbf{2}} / \mathbf{M J}\right)$ \\
\hline \multirow{3}{*}{ Bioethanol } & Wheat & 34 \\
& Maize & 14 \\
& Barley & 36 \\
& Sugar beet & 15 \\
& Sugar cane & 17 \\
\hline Biomethane & Silage Maize & 21 \\
\hline \multirow{2}{*}{ Biodiesel } & Sunflower oil & 63 \\
& Palm oil & 231 \\
& Rapeseed & 65 \\
\hline Bioethanol & Soybean & 150 \\
\hline \multirow{2}{*}{ FT Biodiesel } & Cereal straw & 16 \\
\hline
\end{tabular}

An analysis of recent studies regarding the ILUC emissions shows varying results and the overall ILUC effects are therefore considered difficult to precisely define [136]. However, wood and crop residues are considered promising as the ILUC GHG emission are considerably lower than the first-generation crop-based biofuels $[129,137]$. The study of [136] does indicate a trend where on average biodiesel has higher ILUC emission (median of $52 \mathrm{~g} \mathrm{CO}_{2}$-eq/MJ) compared to first-generation ethanol (median of $21 \mathrm{~g} \mathrm{CO}_{2}$-eq/MJ), with the sugar crops showing the lowest ILUC emissions.

The negative effect of the application of crops as a biofuel feedstock is once more highlighted by the land-use emission analysis. The general emission from the biofuel supply chain already did not depict favorable equivalent $\mathrm{CO}_{2}$ factors. Overall, the environmental sustainability of crop feedstocks is impacted especially with the available superior feedstock. Not only the supply chain emissions are competitive, but the residue streams as feedstock also do not impose the land-use impacts seen by the first-generation bioethanol and biodiesel feedstock. In addition to the thermochemical conversion of grasses to biodiesel that shows negative land-use emission, the biochemical conversion of waste oils already shows an environmental favorable supply chain and the land-use effects are not applicable.

\subsection{Socioecological Aspects}

The essence of the socioecological sustainability originates from the origin of the feedstock, whether it is cultivated on agricultural land or a waste stream from an industrial process for example. Considering only first-generation bioethanol and biodiesel, the study of [138] analyzed the water, land, and food use with data from $85 \%$ of the global bioethanol consumption and $81 \%$ of the global biodiesel consumption in 2013. The results indicate that for only crop feedstock, biodiesel requires on average $90,000 \mathrm{~m}^{3} / \mathrm{TJ}$ of water compared to $74,000 \mathrm{~m}^{3} / \mathrm{TJ}$ for bioethanol. The land required is on 
average $9 \mathrm{ha} / \mathrm{TJ}$ for bioethanol and $29 \mathrm{ha} / \mathrm{TJ}$ for biodiesel. However, based on the food calories used for the production of the first-generation biofuels, the biodiesel is less competitive with the food industry with an average of 95 people/TJ of biodiesel that could be fed compared to 107 people/TJ of bioethanol. Considering the production processes of both bioethanol and biodiesel it can thus be concluded that the overall efficiency of land to biofuel is significantly lower for biodiesel. However, the use of waste oils, for example, the waste cooking oils from households, does not require the extraction processes compared to the oil crops, which would favor the increase the production yields per volume of feedstock used. In comparison, the biochemical production of bioethanol from lignocellulosic biomass still does not convert all biomass to biofuel. The thermochemical conversion technologies would reduce the waste stream since the complete biomass can be converted to syngas. However, this does not directly implicate that thermochemical conversion can produce more biofuel from less land since not all the feedstock has the same amount of bioethanol yield. Moreover, the biochemical production processes do consider the recycling of waste streams such as the use of lignin to generate the required heat for the process, as discussed in the conversion technologies. Overall, the distinction between food and non-food feedstock is essential for the discussion and implication of land use, as is recognized by the European Commission, which presented the Indirect Land Use Change (ILUC) Directive in 2015 to tackle those negative effects of food-based feedstock. It limits the share of biofuels from crops grown on agricultural land to 7\% and directs the Member States of the EU to develop national targets for the second generation biofuels [34].

Considering the feedstock for biomethane, the biofuel has a strong socioecological position due to the extensive possibilities in the application of feedstock other than complete agricultural crops. However, bioethanol could still be a competitive biofuel as national targets are set to develop the production from lignocellulosic biomass. On the other hand, biodiesel production from used cooking oils is even more technologically mature, as it is the feedstock for $86 \%$ of the UK biodiesel [139]. Thermochemical conversion to syngas implies that the same feedstock can be used for all three biofuels, implying that socioecological sustainability is less a decisive factor for the biofuel choice with this technology. Since the feedstock for the gasification process originates mainly from residues and biomass, the impact of thermochemical production on the socioecological sustainability factors will generally be less as to the biochemical conversion pathway, especially with the food crop feedstock. However, conversion efficiencies of the different technology could reduce this effect and would increase the possibilities for feedstock that impose less pressure on agricultural land use.

To reduce the impact of land use and the competition with the food industry there are crops that are non-edible and grow well on marginal lands including the discussed Jatropha (Bhuiya et al., 2016). However, similar to the other crops, these crops do also require significant amounts of water to grow and cultivate compared to the water footprint of crop residues [140]. Table 7 is indicative of the reduction in water use if residues of crops are used for biofuel production instead of complete crops. It would only be favorable if the residues could be obtained from normal agricultural activities, such that it is a waste stream of another industry instead of specially cultivated to produce biofuel. Further analysis of the crop yields in Table 7 shows that the water footprint is lowest for the sugar feedstock used for bioethanol and that the oil crops for biodiesel have a higher water footprint. This is the same trend as depicted by the first-generation biofuel data of [138] as discussed.

The change in biodiversity due to the biofuel industry is mainly driven by land use [141]. The negative impact of deforestation on biodiversity has already been described. However, for the conversion of abandoned cropland or marginal lands to biofuel croplands, the impacts are not that clear. In general, the use of the second-generation crops is considered to have a less negative influence on the biodiversity compared to the first-generation [141]. The improvements in the biodiversity impacts by the cultivation of second-generation feedstock are also supported by the study of [142]. 
Table 7. The water footprint in $\mathrm{m}^{3}$ per ton of crop yields and residues. It states the amount of water used in growing the useful part of the crop (the yield), and for what is considered the residue [140].

\begin{tabular}{ccc}
\hline Crop & Water Footprint of Crop Yield $\left.\mathbf{~ ( m}^{\mathbf{3}} \mathbf{/ t}\right)$ & Water Footprint Residue $\left.\mathbf{( m}^{\mathbf{3}} / \mathbf{t}\right)$ \\
\hline Sugar cane & 176 & 72 \\
Corn & 961 & 205 \\
Rice & 1523 & 129 \\
Wheat & 1633 & 140 \\
Sugar beet & 103 & 47 \\
Cassava & 476 & 87 \\
Soybean & 2002 & 188 \\
Rapeseed & 1583 & 205 \\
Cotton & 3796 & 154 \\
Sunflower & 2014 & 636 \\
\hline
\end{tabular}

For the food competition and water use issues, the important driver is the type of feedstock and the land that cultivation requires. Biodiversity does also improve by minimization of crop feedstock but is to a higher extent influenced by the type of land that is converted for cultivation [142]. In other words, biodiversity is the easier factor of the socioecological facet to improve by creating legislation that restricts certain areas of land to be used for cultivation of biofuel crops.

\subsection{Geopolitical Substratum}

Towards the renewable energy goals of the EU of the year 2020, all 28 member states are obliged to report on their progress every two years. The binding target for the transportation sector is to obtain a renewable energy share of at least 10\%, which support the development of the biofuel industry to achieve this target $[12,33]$. As the biofuels are developed as renewable energies, the environmental and socioecological facets can be considered as drivers for the biofuel policies. Therefore, the geopolitical sustainability, the extent to which distinctive parts of the biofuel industry are supported by the geographic characteristics and the developed policies, is strongly affected by the assessment of its environmental and socioecological sustainability. A substantial amount of the current policies now incorporates a system of certification that ensures sustainable production of biofuels. To which extent the term 'sustainable' includes all facets covered in this research is difficult to determine, but the programs were initiated after the publication of reports about the interrelation of biofuel production and food shortages, biodiversity loss, and the land-use change [143]. Moreover, to directly reduce the impact of food crops on these types of issues, a restriction is introduced which limits the use of food crops, the sugar, starch, and oil crops, to $7 \%$ of all the feedstock used to produce biofuel.

Among the EU member states, Germany is the country with the highest level of development of bioenergy. Their target for the transportation sector is set at $13.8 \%$ renewable energy by 2020 [144], aiming above the guideline of the EU. In comparison, Poland has aligned the 2020 target of renewable energy in transport with the minimum $10 \%$ imposed by the EU but aiming for $8.5 \%$ renewable fuels and $1.5 \%$ contribution from electricity used in transport [145].

The Netherlands was the first, in 2009, EU country to have legislation in place that supported the production of biofuels from waste, residues, and lignocellulosic biomass by counting these advanced biofuels double towards the targets set for the industry [146]. In practice, these types of biofuel contributed for $50 \%$ to the total renewable energy used in the Netherlands in 2016, of which used cooking oil and animal fats for biodiesel production were the primary sources. Recently, Italy as a pioneer legally required all fuel suppliers to include $0.6 \%$ advanced biofuels in the gasoline and diesel produced from 2018 [147]. In contrast, Poland did not implement the directive supporting the advanced biofuel in its legal system, including a double counting system, until 2018 [145]. Hence, no data on the use of this type of feedstock in biofuel production is available in the prior years. Romania, another country in non-western Europe, experiences similar problems in supporting advanced biofuels. In this case, they explicitly refer to budgetary problems that limit their development of support schemes 
especially required for the infrastructure that is needed to produce the more costly biofuels from wastes, residues, and lignocellulosic biomass [148].

Overall in the EU, there is a direct intention to limit the use of first-generation biofuels. The alternatives, including the use of waste and residues, do require additional support that cannot yet be provided by all countries. Hence, the geopolitical sustainability of food crop-based biofuels decreases, while the use of advanced biofuels is increasingly promoted. However, in the current state of policies, the economic support for advanced biofuels seems more developed in western Europe, whereas other countries face difficulties in providing a support system that can lower the higher capital cost of advanced biofuel production.

The development of the biofuel industry can be linked to the availability of feedstock as input to the production process. From Figures 3 and 4, it can be derived that, especially for bioethanol, a large majority of the feedstock used for the EU biofuel industry originate from Europe itself. Regarding the support of the biofuel industry by the development of policies, the application of native feedstock will support policies that address the whole supply chain of the biofuel industry. However, there are a growing number of voluntary schemes that can be used worldwide to prove compliance with the EU biofuel sustainability criteria. The $63.7 \%$ of biodiesel produced with feedstock from the EU originates for $33 \%$ from used cooking oil and animal fats [149]. These feedstock types are available worldwide and meet the trend of requirements set for the sustainability of biofuel feedstock. The $20.6 \%$ of feedstock imported from Malaysia and Indonesia, which is primarily palm oil, is not compliant with the developing policies. Recent criteria set by the EU deem all the palm oil produced on land larger than 2 ha unsustainable, which implies that biofuel from palm oil cannot be counted towards the renewable energy targets imposed by the EU [150].

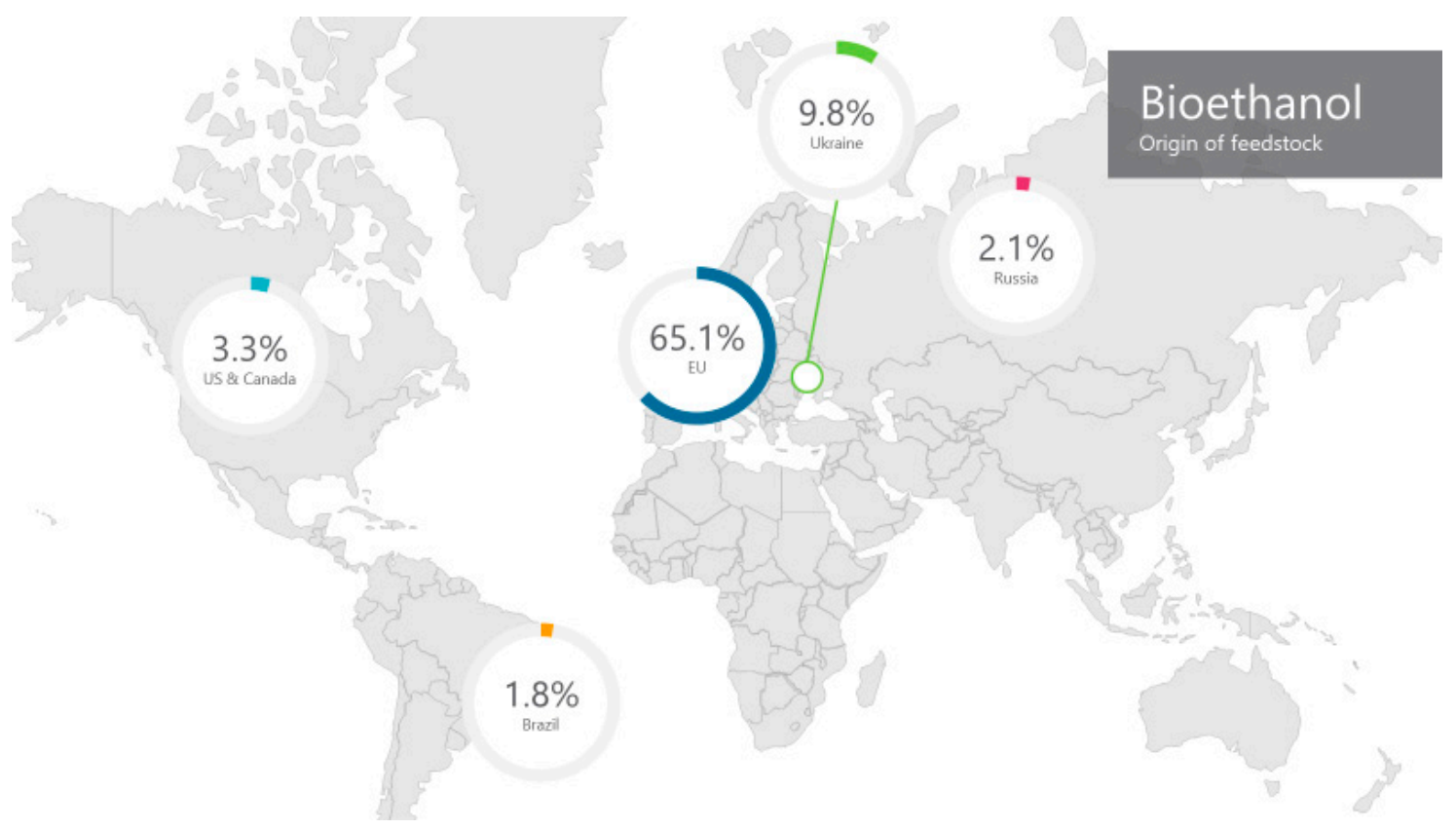

Figure 3. The origin of the feedstock used for bioethanol consumed in the EU in 2016. The percentages with respect to the total bioethanol consumption are included. The figure is adapted from data of [149]. 


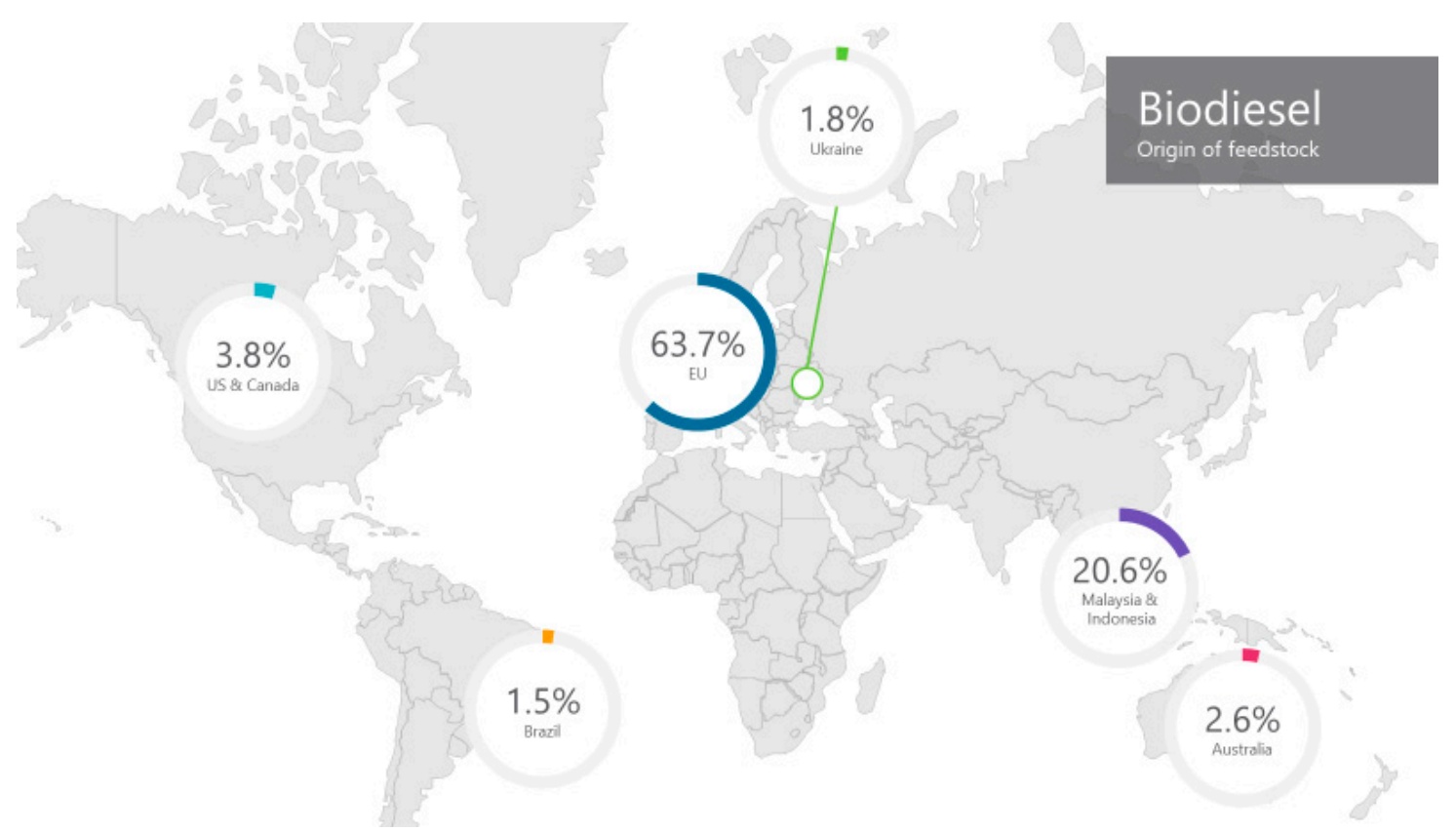

Figure 4. The origin of the feedstock used for biodiesel consumed in the EU in 2016. The percentages with respect to the total biodiesel consumption are included. The figure is adapted from data of [149].

The creation of the national laws to achieve the targets of EU is empowered in the RED, on the only condition that there is no legislation that restricts the free movement of fuels and feedstocks among the EU countries [150]. For countries outside of the EU, anti-dumping duties are imposed on, for example, the US ethanol in 2013, since that market price was below what EU producers could offer [151]. Hence, the consensus among the EU countries appears to be the use of the EU biofuel market to support the development of the EU production companies. This trend, together with the extent of imposed EU tariffs on biofuel, drives the EU towards the creation of an isolated biofuel market [151]. Depending on the trade of the feedstock, such an isolated market will have more impact on the variety of feedstocks used in the EU biofuel than on the distribution of the biofuel types that are consumed, since, for all biofuels, the necessary feedstock is available in the EU itself.

\section{Discussion}

From the start of this integration project, a broad research-oriented approach is deemed suited to address the existing knowledge gap that restricted biofuel development. The variety of the production characteristics and sustainability factors that are analyzed as a result of this approach highlight the complexity of the industry faced by policymakers and production companies. The research structures this complexity by identifying key relationships between the industry and its sustainability. However, some relationships are more extensively discussed and highlighted compared to others due to the lack of recent representative research. Further research could, for example, specifically address production characteristics of the biogas upgrading for the biomethane production to allow a more equal comparison with the more mature bioethanol and biodiesel processes. Moreover, further research should build on the positive relationships between a production characteristic and the sustainability identified in this research by analyzing how to optimize the positive effect and neutralize additional consequences on other sustainability facets. That knowledge will contribute to effective future development of biofuels by companies and governments while ensuring its sustainability.

An understanding of the key aspects of the biofuel production process and how they all affect the sustainability of the industry can contribute to the sustainable development of biofuels. To address the existing knowledge gap, this research correlates key production characteristics of bioethanol, biodiesel, and biomethane with the sustainability factors that are affected by the biofuel industry. The results 
show a significant number of possibilities in the supply chain of the biofuel industry. First, the feedstock for bioethanol and biodiesel can either be food crops, the first-generation, or lignocellulosic biomass, waste and residue streams, the second-generation. For biomethane, the main feedstock sources are waste and by-products from the agricultural, industrial, and municipal sectors. Second, the conversion process of feedstock to biofuel can be subdivided in the biochemical and the thermochemical pathway. The latter is commercially available as the syngas-route, where lignocellulosic biomass is the most common renewable feedstock.

The correlation executed in the research shows that the current technological developments in the industry significantly affect the competitiveness between different production characteristics with respect to economic sustainability. The characteristics of biomethane show a good potential to maintain a competitive production cost both in the current perspective as in the near future. The low feedstock cost of the second-generation biofuels gives a competitive advantage to the lignocellulosic bioethanol and biodiesel from waste oils via the biochemical production pathway which will only increase over time as the technologies become more mature. In general, the biofuels from lignocellulosic biomass produced via the thermochemical pathway become also more competitive as the capital cost will decrease. Overall, the economic sustainability of biodiesel and bioethanol from crop feedstock will decrease as the alternatives and their conversion technology develop.

The environmental impacts of the different biofuels differ significantly. Biomethane and biodiesel from waste oils show favorable properties because there are no emissions from crop cultivation and the land-use impacts are minimized. The ability to use the feedstock to generate energy contributes to a reduction in emission for some crops, including sugar cane and wheat, and the biofuels produced from lignocellulosic biomass. The latter also avoids largely all impacts from land use and land-use change. Additionally, the impact of land use and land-use change induced by crop feedstock affects socioecological sustainability. The use of residues and waste streams would reduce the impact on food competition, water use, and biodiversity. Biomethane shows the largest number of possibilities in avoiding crop feedstock and using different waste and residue stream. For the use of food crops, the environmental and socio-ecological sustainability of the bioethanol production process shows more favorable results compared to biodiesel production.

The drive for the biofuel production still originates from EU directives and the related government legislation. In policy development, there is a focus on the feedstock types and their origin, with limitations for the use of crop feedstock and the first initiatives being introduced that support the second-generation biofuels. However, the development is not uniform for all the EU countries, as not all countries have the economic capacity and infrastructure required for such extensive support. Overall, the results of the correlation can be used as the starting point for a multiple-scenario assessment which is required to develop a policy that supports the sustainable development of biofuels. Moreover, production companies can start an assessment of their production characteristics to ensure that these will suit future policies incorporating the importance of sustainable development.

\section{Summary}

A broad research-oriented approach was deemed suitable to address the existing knowledge gap that restricts biofuel development. The variety of the production characteristics and sustainability factors, that were analyzed as a result of this approach, highlight the complexity of the industry faced by policymakers and production companies. The research structured this complexity by identifying key relationships between the industry and its sustainability. However, some relationships were more extensively discussed and highlighted compared to others due to the lack of recent representative research. Further research could, for example, specifically address production characteristics of the biogas upgrading for the biomethane production to allow a more equal comparison with the more mature bioethanol and biodiesel processes. Moreover, further research should be built on the positive relationships between a production characteristic and the sustainability identified in this research by analysing how to optimize the positive effect and neutralise additional consequences on other 
sustainability facets. That knowledge will contribute to an effective future development of biofuels by companies and governments while ensuring its sustainability.

Author Contributions: Conceptualization, S.A.; methodology, S.A.; writing-original draft preparation, J.H. and S.A.; writing—review and editing, V.A. and G.J.W.E.

Funding: This research received no external funding.

Conflicts of Interest: The authors declare no conflict of interest.

\section{References}

1. Cook, P.J. CCS research development and deployment in a clean energy future: Lessons from Australia over the past two decades. Engineering 2017, 3, 477-484. [CrossRef]

2. Hoque, K.M.R.; Ozansoy, C.; Fahrioglu, M. Climate and size correction in European Union's Waste Framework Directive and R1 energy efficiency criteria. Waste Manag. Res. 2018, 36, 670-688. [CrossRef] [PubMed]

3. Longinos, S.N.; Bülbül, S.; Parlaktuna, M. Potential effects of methane hydrates to the environment. In Proceedings of the 12th Panhellenic Scientific Conference in Chemical Engineering, Athens, Greece, 29-31 May 2019.

4. Merey, S.; Longinos, S.N. The gas hydrate potential of the Eastern Mediterranean basin. Bull. Min. Res. Exp. 2019, 159, 1-10. [CrossRef]

5. Merey, S.; Longinos, S.N. The role of natural gas hydrate during natural gas transportation. OHU J. Eng. Sci. 2018, 7, 937-953. [CrossRef]

6. Longinos, S.N.; Merey, S. $\mathrm{CO}_{2}$ sequestration in the mature oil fields: A case study of Bati Raman oil field, Turkey. In Proceedings of the International Conference on Energy Research, Alanya, Turkey, 31 October-2 November 2018.

7. Longinos, S.N. Potential Environmental Challenges for Gas Hydrates, 1st ed.; Lap Lambert Academic Publishing: Riga, Latvia, 2019; pp. 1-60.

8. Davis, L.A. The shale oil and gas revolution. Engineering 2018, 4, 438-439. [CrossRef]

9. Ranieri, L.; Mossa, G.; Pellegrino, R.; Digiesi, S. Energy recovery from the organic fraction of Municipal Solid Waste: A real options-based facility assessment. Sustainability 2018, 10, 368. [CrossRef]

10. Gowreesunker, B.L.; Tassou, S.; Atuonwu, J. Cost-energy optimum pathway for the UK food manufacturing industry to meet the UK national emission targets. Energies 2018, 11, 2630. [CrossRef]

11. Ajanovic, A. Biofuels versus food production: Does biofuels production increase food prices? Energy 2011, 36, 2070-2076. [CrossRef]

12. European Commission. Biofuels. 2019. Available online: https:/ec.europa.eu/energy/en/topics/renewableenergy/biofuels (accessed on 15 May 2019).

13. European Commission. Renewable Energy Directive. 2019. Available online: https://ec.europa.eu/energy/en/ topics/renewable-energy/renewable-energy-directive (accessed on 26 March 2019).

14. Linares, P.; Pérez-Arriaga, I.J. A sustainable framework for biofuels in Europe. Energy Policy 2013, 52, 166-169. [CrossRef]

15. Zhang, Z.; Han, W.; Chen, X.; Yang, N.; Lu, C.; Wang, Y. The Life-Cycle Environmental impact of recycling of restaurant food waste in Lanzhou, China. Appl. Sci. 2019, 9, 3608. [CrossRef]

16. Domínguez, J.; Gómez-Brandón, M.; Martínez-Cordeiro, H.; Lores, M. Bioconversion of Scotch broom into a high-quality organic fertiliser: Vermicomposting as a sustainable option. Waste Manag. Res. 2018, 36, 1092-1099. [CrossRef]

17. Trakulvichean, S.; Chaiprasert, P.; Otmakhova, J.; Songkasiri, W. Comparison of fermented animal feed and mushroom growth media as two value-added options for waste Cassava pulp management. Waste Manag. Res. 2017, 35, 1210-1219. [CrossRef] [PubMed]

18. Longjan, G.G.; Dehouche, Z. Nutrient characterisation and bioenergy potential of common Nigerian food wastes. Waste Manag. Res. 2018, 36, 426-435. [CrossRef] [PubMed]

19. Noya, I.; Inglezakis, V.; González-García, S.; Katsou, E.; Feijoo, G.; Moreira, M. Comparative environmental assessment of alternative waste management strategies in developing regions: A case study in Kazakhstan. Waste Manag. Res. 2018, 36, 689-697. [CrossRef] [PubMed] 
20. Di Maria, F.; Sisani, F. Effectiveness of municipal solid waste incinerators in replacing other fuels. A primary energy balance approach for the EU28. Waste Manag. Res. 2018, 36, 942-951. [CrossRef] [PubMed]

21. Muradin, M.; Joachimiak-Lechman, K.; Foltynowicz, Z. Evaluation of eco-efficiency of two alternative agricultural biogas plants. Appl. Sci. 2018, 8, 2083. [CrossRef]

22. Charalampidis, I.; Karkatsoulis, P.; Capros, P. A regional economy-energy-transport model of the EU for assessing decarbonization in transport. Energies 2019, 12, 3128. [CrossRef]

23. Ribeiro, E.M.; Mambeli Barros, R.; Tiago Filho, G.L.; dos Santos, I.F.S.; Sampaio, L.C.; dos Santos, T.V.; de Freitas, J.V.R. Feasibility of biogas and energy generation from poultry manure in Brazil. Waste Manag. Res. 2018, 36, 221-235. [CrossRef]

24. Philippidis, G.; Bartelings, H.; Helming, J.; M'barek, R.; Smeets, E.; Van Meijl, H. The good, the bad and the uncertain: Bioenergy use in the European Union. Energies 2018, 11, 2703. [CrossRef]

25. Lauer, M.; Thrän, D. Flexible biogas in future energy systems-Sleeping beauty for a cheaper power generation. Energies 2018, 11, 761. [CrossRef]

26. Ferreira, E.T.D.F.; Balestieri, J.A.P. Comparative analysis of waste-to-energy alternatives for a low-capacity power plant in Brazil. Waste Manag. Res. 2018, 36, 247-258. [CrossRef] [PubMed]

27. Manni, M.; Coccia, V.; Cavalaglio, G.; Nicolini, A.; Petrozzi, A. Best practices for recovering rural abandoned towers through the installation of small-scale biogas plants. Energies 2017, 10, 1224. [CrossRef]

28. Park, J.K.; Chong, Y.G.; Tameda, K.; Lee, N.H. Methods for determining the methane generation potential and methane generation rate constant for the FOD model: a review. Waste Manag. Res. 2018, 36, $200-220$. [CrossRef] [PubMed]

29. Achinas, S.; Achinas, V.; Euverink, G.J.W. A technological overview of biogas production from biowaste. Engineering 2017, 3, 299-307. [CrossRef]

30. Lindkvist, E.; Johansson, M.T.; Rosenqvist, J. Methodology for analysing energy demand in biogas production plants-A comparative study of two biogas plants. Energies 2017, 10, 1822. [CrossRef]

31. Safar, K.M.; Bux, M.R.; Aslam, U.M.; Shankar, B.A.; Goel, R.K. The feasibility of putrescible components of municipal solid waste for biomethane production at Hyderabad, Pakistan. Waste Manag. Res. 2018, 36, 169-182. [CrossRef] [PubMed]

32. EurObserv'ER. The state of renewable energies in Europe. In 18th EurObserv'ER Report; EurObserv'ER: Paris, France, 2018.

33. European Commission. Renewable Energy: Progress Reports. 2019. Available online: https://ec.europa.eu/ energy/en/topics/renewable-energy/progress-reports (accessed on 27 May 2019).

34. European Environment Agency. Renewable Energy in Europe-2018: Recent Growth and Knock-on Effects; European Environment Agency: Copenhagen, Denmark, 2018.

35. Royal Academy of Engineering. Sustainability of Liquid Biofuels; Royal Academy of Engineering: London, UK, 2017.

36. Moeller, L.; Bauer, A.; Wedwitschka,H.; Stinner, W.; Zehnsdorf, A. Crop characteristics of aquatic macrophytes for use as a substrate in anaerobic digestion plants-A study from Germany. Energies 2018, 11, 3016. [CrossRef]

37. Reißmann, D.; Thrän, D.; Bezama, A. How to identify suitable ways for the hydrothermal treatment of wet bio-waste? A critical review and methods proposal. Waste Manag. Res. 2018, 36, 912-923. [CrossRef]

38. Chatzikonstantinou, D.; Tremouli, A.; Papadopoulou, K.; Kanellos, G.; Lampropoulos, I.; Lyberatos, G. Bioelectricity production from fermentable household waste in a dual-chamber microbial fuel cell. Waste Manag. Res. 2018, 36, 1037-1042. [CrossRef]

39. Benato, A.; Macor, A. biogas engine waste heat recovery using organic rankine cycle. Energies 2017, $10,327$. [CrossRef]

40. Li, J.; Huang, H.; Huhetaoli; Osaka, Y.; Bai, Y.; Kobayashi, N.; Chen, Y. Combustion and heat release characteristics of biogas under hydrogen- and oxygen-enriched condition. Energies 2017, 10, 1200. [CrossRef]

41. Rosero-Henao, J.C.; Bueno, B.E.; de Souza, R.; Ribeiro, R.; Lopes de Oliveira, A.; Gomide, C.A.; Gomes, T.M.; Tommaso, G. Potential benefits of near critical and supercritical pre-treatment of lignocellulosic biomass towards anaerobic digestion. Waste Manag. Res. 2019, 37, 74-82. [CrossRef] [PubMed]

42. Oreggioni, G.D.; Gowreesunker, L.B.; Tassou, S.A.; Bianchi, G.; Reilly, M.; Kirby, M.E.; Toop, T.A.; Theodorou, M.K. Potential for energy production from farm wastes using anaerobic digestion in the UK: An economic comparison of different size plants. Energies 2017, 10, 1396. [CrossRef] 
43. Milledge, J.J.; Nielsen, B.V.; Sadek, M.S.; Harvey, P.J. Effect of freshwater washing pretreatment on Sargassum muticum as a feedstock for biogas production. Energies 2018, 11, 1771. [CrossRef]

44. Carlini, M.; Mosconi, E.M.; Castellucci, S.; Villarini, M.; Colantoni, A. An economical evaluation of anaerobic digestion plants fed with organic agro-industrial waste. Energies 2017, 10, 1165. [CrossRef]

45. Bezergianni, S.; Dimitriadis, A.; Faussone, G.-C.; Karonis, D. Alternative diesel from waste plastics. Energies 2017, 10, 1750. [CrossRef]

46. Zhou, Y.; Peng, S.; Huang, X.; Wu, C.; Zhang, J. LNG-air mixture as a supplementary energy injection into a biogas distribution Network. Energies 2017, 10, 1902. [CrossRef]

47. Koçer, A.T.; Özçimen, D. Investigation of the biogas production potential from algal wastes. Waste Manag. Res. 2018, 36, 1100-1105. [CrossRef]

48. Achinas, S.; Euverink, G.J.W. Feasibility study of biogas production from hardly degradable material in co-inoculated bioreactor. Energies 2019, 12, 1040. [CrossRef]

49. Ghanimeh, S.; Khalil, C.A.; Ibrahim, E. Anaerobic digestion of food waste with aerobic post-treatment: Effect of fruit and vegetable content. Waste Manag. Res. 2018, 36, 965-974. [CrossRef]

50. Zhou, Z.; Tang, Y.; Chi, Y.; Ni, M.; Buekens, A. Waste-to-energy: A review of life cycle assessment and its extension methods. Waste Manag. Res. 2018, 36, 3-16. [CrossRef] [PubMed]

51. Carnevale, E.; Molari, G.; Vittuari, M. Used cooking oils in the biogas chain: a technical and economic assessment. Energies 2017, 10, 192. [CrossRef]

52. Achinas, S.; Li, Y.; Achinas, V.; Euverink, G.J.W. Biogas potential from the anaerobic digestion of potato peels: Process performance and kinetics evaluation. Energies 2019, 12, 2311. [CrossRef]

53. Kim, S.; Sung, T.; Kim, K.C. Thermodynamic performance analysis of a biogas-fuelled micro-gas turbine with a bottoming organic rankine cycle for sewage sludge and food waste treatment plants. Energies 2017, 10, 275. [CrossRef]

54. Calabrò, P.; Catalán, E.; Folino, A.; Sánchez, A.; Komilis, D. Effect of three pretreatment techniques on the chemical composition and on the methane yields of Opuntia ficus-indica (prickly pear) biomass. Waste Manag. Res. 2018, 36, 17-29. [CrossRef]

55. Achinas, S.; Euverink, G.J.W. Elevated biogas production from the anaerobic co-digestion of farmhouse waste: Insight into the process performance and kinetics. Waste Manag. Res. 2019, in press. [CrossRef]

56. Sahajwalla, V. Green processes: Transforming waste into valuable resources. Engineering 2018, 4, 309-310. [CrossRef]

57. Chen, P.; Anderson, E.; Addy, M.; Zhang, R.; Cheng, Y.; Peng, P.; Ma, Y.; Fan, L.; Zhang, Y.; Lu, Q.; et al. Breakthrough technologies for the biorefining of organic solid and liquid wastes. Engineering 2018, 4, 574-580. [CrossRef]

58. RedCorn, R.; Fatemi, S.; Engelberth, A.S. Comparing end-use potential for industrial food-waste sources. Engineering 2018, 4, 371-380. [CrossRef]

59. Baute, K.; Van Eerd, L.L.; Robinson, D.E.; Sikkema, P.H.; Mushtaq, M.; Gilroyed, B.H. Comparing the biomass yield and biogas potential of Phragmites australis with Miscanthus $\times$ giganteus and Panicum virgatum Grown in Canada. Energies 2018, 11, 2198. [CrossRef]

60. Matsakas, L.; Gao, Q.; Jansson, S.; Rova, U.; Christakopoulos, P. Green conversion of municipal solid wastes into fuels and chemicals. Electron. J. Biotechnol. 2017, 26, 69-83. [CrossRef]

61. Di Matteo, U.; Nastasi, B.; Albo, A.; Astiaso Garcia, D. energy contribution of OFMSW (Organic Fraction of Municipal Solid Waste) to energy-environmental sustainability in urban areas at small scale. Energies 2017, 10, 229. [CrossRef]

62. Kim, S.; Sung, T.; Kim, K.C. performance and greenhouse gas reduction analysis of biogas-fueled solid-oxide fuel cells for a sewage sludge and food waste treatment facility. Energies 2018, 11, 600.

63. Huang, Q.; Jiang, F.; Wang, L.; Yang, C. Design of photobioreactors for mass cultivation of photosynthetic organisms. Engineering 2017, 3, 318-329. [CrossRef]

64. Xu, J.; Ma, B.; Su, J.; Huang, S.; Xu, X.; Zhou, X.; Huang, X.E.; Knight, R. Emerging trends for microbiome analysis: From single-cell functional imaging to microbiome Big Data. Engineering 2017, 3, 66-70. [CrossRef]

65. Oliveira, A.; Navia, R. Zero waste bio-refineries: The example of Brazilian pulp and paper sector. Waste Manag. Res. 2018, 35, 1193-1194. [CrossRef] [PubMed] 
66. Guo, X.; Kang, K.; Shang, G.; Yu, X.; Qiu, L.; Sun, G. Influence of mesophilic and thermophilic conditions on the anaerobic digestion of food waste: Focus on the microbial activity and removal of long chain fatty acids. Waste Manag. Res. 2018, 36, 1106-1112. [CrossRef]

67. Ahorsu, R.; Medina, F.; Constantí, M. Significance and challenges of biomass as a suitable feedstock for bioenergy and biochemical production: A Review. Energies 2018, 11, 3366. [CrossRef]

68. Ragossnig, A.; Tunesi, S. Succeeding in involving decision-makers in solid waste management planning by setting appropriate goals and providing a structured planning method. Waste Manag. Res. 2018, 36, 924-933. [CrossRef]

69. Chen, F.; Luo, Z.; Yang, Y.; Liu, G.J.; Ma, J. Enhancing municipal solid waste recycling through reorganizing waste pickers: A case study in Nanjing, China. Waste Manag. Res. 2018, 36, 767-778. [CrossRef]

70. Müller, F.P.C.; Maack, G.-C.; Buescher, W. Effects of biogas substrate recirculation on methane yield and efficiency of a liquid-manure-based biogas plant. Energies 2017, 10, 325. [CrossRef]

71. Mortreuil, P.; Baggio, S.; Lagnet, C.; Schraauwers, B.; Monlau, F. Fast prediction of organic wastes methane potential by near infrared reflectance spectroscopy: A successful tool for farm-scale biogas plant monitoring. Waste Manag. Res. 2018, 36, 800-809. [CrossRef] [PubMed]

72. Llewellyn, D. Does global agriculture need another green revolution? Engineering 2018, 4, 449-451. [CrossRef]

73. Anjum, M.; Khalid, A.; Qadeer, S.; Miandad, R. Synergistic effect of co-digestion to enhance anaerobic degradation of catering waste and orange peel for biogas production. Waste Managem. Res. 2017, 35, 967-977. [CrossRef]

74. Roubík, H.; Mazancová, J. Identification of context-specific knowledge as a tool for biogas facilitators and their quality involvement-Using Vietnamese practice as an example. Energies 2019, 12, 1326. [CrossRef]

75. Hildebrandt, J.; Bezama, A. Cross-fertilisation of ideas for a more sustainable fertiliser market: The need to incubate business concepts for harnessing organic residues and fertilisers on biotechnological conversion platforms in a circular bioeconomy. Waste Manag. Res. 2018, 36, 1125-1126. [CrossRef]

76. Franco, R.T.; Coarita, H.; Bayard, R.; Buffière, P. An improved procedure to assess the organic biodegradability and the biomethane potential of organic wastes for anaerobic digestion. Waste Manag. Res. 2019, 37, 746-754. [CrossRef]

77. Kannavou, M.; Zampara, M.; Capros, P. Modelling the EU internal electricity market: The PRIMES-IEM Model. Energies 2019, 12, 2887. [CrossRef]

78. Christidis, P.; Focas, C. Factors affecting the uptake of hybrid and electric vehicles in the European Union. Energies 2019, 12, 3414. [CrossRef]

79. Statharas, S.; Moysoglou, Y.; Siskos, P.; Zazias, G.; Capros, P. Factors influencing electric vehicle penetration in the EU by 2030: A Model-Based Policy Assessment. Energies 2019, 12, 2739. [CrossRef]

80. Achinas, S.; Achinas, V. Biogas combustion: An introductory briefing. In Biogas: Production, Applications and Global Developments; Vico, A., Artemio, N., Eds.; Nova Science Publishers, Inc.: New York, NY, USA, 2017; pp. 179-193.

81. Gao, Y.; Kong, X.; Xing, T.; Sun, Y.; Zhang, Y.; Luo, X.; Sun, Y. Digestion performance and microbial metabolic mechanism in thermophilic and mesophilic anaerobic digesters exposed to elevated loadings of organic fraction of municipal solid waste. Energies 2018, 11, 952. [CrossRef]

82. Wagner, O.; Lackner, N.; Mutschlechner, M.; Prem, E.M.; Markt, R.; Illmer, P. Biological pretreatment strategies for second-generation lignocellulosic resources to enhance biogas production. Energies 2018, 11, 1797. [CrossRef] [PubMed]

83. Zielińska, K.; Fabiszewska, A.; Świątek, M.; Szymanowska-Powałowska, D. Evaluation of the ability to metabolize 1,2-propanediol by heterofermentative bacteria of the genus Lactobacillus. Electron. J. Biotechnol. 2017, 26, 60-63.

84. Nelson, M.J.; Nakhla, G.; Zhu, J. Fluidized-bed bioreactor applications for biological wastewater treatment: A review of research and developments. Engineering 2017, 3, 330-342. [CrossRef]

85. Okoro, O.V.; Sun, Z.; Birch, J. Prognostic assessment of the viability of hydrothermal liquefaction as a post-resource recovery step after enhanced biomethane generation using co-digestion technologies. Appl. Sci. 2018, 8, 2290. [CrossRef]

86. Achinas, S.; Euverink, G.J.W. Effect of combined inoculation on biogas production from hardly degradable material. Energies 2019, 12, 217. [CrossRef] 
87. Boonpiyo, S.; Sittijunda, S.; Reungsang, A. Co-digestion of napier grass with food waste and napier silage with food waste for methane production. Energies 2018, 11, 3200. [CrossRef]

88. Wu, Y.; Li, T.; Cao, Q.; Li, X.; Zhang, Y.; Tan, X. RecET recombination system driving chromosomal target gene replacement in Zymomonas mobilis. Electron. J. Biotechnol. 2017, 30, 118-124. [CrossRef]

89. Chiumenti, A.; Boscaro, D.; da Borso, F.; Sartori, L.; Pezzuolo, A. Biogas from fresh spring and summer grass: Effect of the harvesting period. Energies 2018, 11, 1466. [CrossRef]

90. Sadala, S.; Dutta, S.; Raghava, R.; Jyothsna, T.S.; Chakradhar, B.; Ghosh, S.K. Resource recovery as alternative fuel and raw material from hazardous waste. Waste Manag. Res. 2019, 37, 1063-1076. [CrossRef]

91. Mamimin, C.; Prasertsan, P.; Kongjan, P.; O-Thong, S. Effects of volatile fatty acids in biohydrogen effluent on biohythane production from palm oil mill effluent under thermophilic condition. Electron. J. Biotechnol. 2017, 29, 78-85. [CrossRef]

92. Świątek, M.; Soo, C.S.; Yap, W.S.; Hon, W.M.; Ramli, N.; Kalsom Md Shah, U.; Phang, L.Y. Improvement of hydrogen yield of ethanol-producing Escherichia coli recombinants in acidic conditions. Electron. J. Biotechnol. 2017, 26, 27-32.

93. Marcos, A.C.; Al-Kassir, A.; Cuadros, F.; Yusaf, T. Treatment of slaughterhouse waste water mixed with Serum from Lacteal Industry of Extremadura in Spain to Produce Clean Energy. Energies 2017, $10,765$. [CrossRef]

94. Morales-Polo, C.; Cledera-Castro, M.D.M.; Moratilla Soria, B.Y. Reviewing the anaerobic digestion of food waste: From waste generation and anaerobic process to its perspectives. Appl. Sci. 2018, 8, 1804. [CrossRef]

95. Mangoyana, R.B.; Smith, T.F.; Simpson, R. A systems approach to evaluating sustainability of biofuel systems. Renew. Sustain. Energy Rev. 2013, 25, 371-380. [CrossRef]

96. Eisentraut, A. Sustainable Production of Second-Generation Biofuels. In Potential and Perspectives in Major Economies and Developing Countries; Internation Energy Agency: Paris, France, 2010.

97. Lazaroiu, G.; Mihaescu, L.; Negreanu, G.; Pana, C.; Pisa, I.; Cernat, A.; Ciupageanu, D.-A. Experimental investigations of innovative biomass energy harnessing solutions. Energies 2018, 11, 3469. [CrossRef]

98. Černý, M.; Vítězová, M.; Vítěz, T.; Bartoš, M.; Kushkevych, I. Variation in the distribution of hydrogen producers from the Clostridiales order in biogas reactors depending on different input substrates. Energies 2018, 11, 3270. [CrossRef]

99. Chen, J.F. Green chemical engineering. Engineering 2017, 3, 283-284. [CrossRef]

100. Nelabhotla, A.B.T.; Dinamarca, C. Bioelectrochemical $\mathrm{CO}_{2}$ reduction to methane: MES integration in biogas production processes. Appl. Sci. 2019, 9, 1056. [CrossRef]

101. Macedonio, F.; Drioli, E. Membrane engineering for green process engineering. Engineering 2017, 3, $290-298$. [CrossRef]

102. Diaz-Chavez, R.A. Assessing biofuels: Aiming for sustainable development or complying with the market? Energy Policy 2011, 39, 5763-5769. [CrossRef]

103. Junginger, M.; Van Dam, J.; Zarrilli, S.; Mohamed, F.A.; Marchal, D.; Faaij, A. Opportunities and barriers for international bioenergy trade. Energy Policy 2011, 39, 2028-2042. [CrossRef]

104. Festel, G.; Würmseher, M.; Rammer, C. Scaling and Learning Effects of Biofuels Conversion Technologies. Energy Technol. 2004, 2, 612-617. [CrossRef]

105. De Souza Guimarães, C.; da Silva Maia, D.R.; Serra, E.G. Construction of biodigesters to optimize the production of biogas from anaerobic co-digestion of food waste and sewage. Energies 2018, 11, 870. [CrossRef]

106. Nitsche, M.; Hensgen, F.; Wachendorf, M. Using grass cuttings from sports fields for anaerobic digestion and combustion. Energies 2017, 10, 388. [CrossRef]

107. Li, W.-W.; Yu, H.-Q. Advances in energy-producing anaerobic biotechnologies for municipal wastewater treatment. Engineering 2016, 2, 438-446. [CrossRef]

108. Solarte-Toro, J.C.; Chacón-Pérez, Y.; Cardona-Alzate, C.A. Evaluation of biogas and syngas as energy vectors for heat and power generation using lignocellulosic biomass as raw material. Electron. J. Biotechnol. 2018, 33, 52-62. [CrossRef]

109. Wang, J.; Wang, H.; Fan, Y. Techno-economic challenges of fuel cell commercialization. Engineering 2018, 4, 352-360. [CrossRef]

110. Seneesrisakul, K.; Sutabutr, T.; Chavadej, S. The effect of temperature on the methanogenic activity in relation to micronutrient availability. Energies 2018, 11, 1057. [CrossRef] 
111. Baek, G.; Kim, J.; Kim, J.; Lee, C. Role and potential of direct interspecies electron transfer in anaerobic digestion. Energies 2018, 11, 107. [CrossRef]

112. Franchi, O.; Rosenkranz, F.; Chamy, R. Key microbial populations involved in anaerobic degradation of phenol and p-cresol using different inocula. Electron. J. Biotechnol. 2018, 35, 33-38. [CrossRef]

113. Musa, M.A.; Idrus, S.; Che Man, H.; Nik Daud, N.N. Wastewater treatment and biogas recovery using Anaerobic Membrane Bioreactors (AnMBRs): Strategies and Achievements. Energies 2018, 11, 1675. [CrossRef]

114. Lemões, J.S.; e Silva, C.F.L.; Avila, S.P.F.; Montero, C.R.S.; e Silva, S.D.D.A.; Samios, D.; do Carmo Ruaro Peralba, M. Chemical pretreatment of Arundo donax L. for second-generation ethanol production. Electron. J. Biotechnol. 2018, 31, 67-74. [CrossRef]

115. Duan, N.; Ran, X.; Li, R.; Kougias, P.G.; Zhang, Y.; Lin, C.; Liu, H. Performance evaluation of mesophilic anaerobic digestion of chicken manure with algal digestate. Energies 2018, 11, 1829. [CrossRef]

116. UNEP. The Bioenergy and Water Nexus; Oeko-Institut and IEA Bioenergy Task 43; UNEP: Nairobi, Kenya, 2011.

117. Koizumi, T. Biofuels and food security. Renew. Sustain. Energy Rev. 2015, 52, 829-841. [CrossRef]

118. European Commission. Renewable Energy in Europe-2018; European Environment Agency: Copenhagen, Denmark, 2018.

119. Cherubini, F.; Bird, N.D.; Cowie, A.; Jungmeier, G.; Schlamadinger, B.; Woess-Gallasch, S. Energy- and greenhouse gas-based LCA of biofuel and bioenergy systems: Key issues, ranges and recommendations. Resour. Conserv. Recycl. 2009, 53, 434-447. [CrossRef]

120. Cherubini, F.; Strømman, A.H. Life cycle assessment of bioenergy systems: State of the art and future challenges. Bioresour. Technol. 2011, 102, 437-451. [CrossRef]

121. Havlik, P.; Schneider, U.A.; Schmid, E.; Böttcher, H.; Fritz, S.; Skalský, R.; Aoki, K.; De Cara, S.; Kindermann, G.; Kraxner, F.; et al. Global land-use implications of first and second generation biofuel targets. Energy Policy 2011, 39, 5690-5702. [CrossRef]

122. Overmars, K.P.; Stehfest, E.; Ros, J.P.; Prins, A.G. Indirect land use change emissions related to EU biofuel consumption: An analysis based on historical data. Environ. Sci. Policy 2011, 14, 248-257. [CrossRef]

123. Hellmann, F.; Verburg, P.H. Impact assessment of the European biofuel directive on land use and biodiversity. J. Environ. Manag. 2010, 91, 1389-1396. [CrossRef]

124. International Renewable Energy Agency. Innovation Outlook: Advanced Liquid Biofuels; International Renewable Energy Agency: Abu Dhabi, UAE, 2016.

125. Festel, G.; Würmseher, M.; Rammer, C.; Boles, E.; Bellof, M. Modelling production cost scenarios for biofuels and fossil fuels in Europe. J. Clean. Prod. 2014, 66, 242-253. [CrossRef]

126. FAO. FAOSTAT Database; Food and Agriculture Organization of the United Nations: Rome, Italy, 2017.

127. Millinger, M.; Thrän, D. Biomass price developments inhibit biofuel investments and research in Germany; The crucial future role of high yields. J. Clean. Prod. 2018, 172, 1654-1663. [CrossRef]

128. Strengers, B.; Overmars, K.; Kram, T.; Ros, J. Greenhouse Gas Impact of Bioenergy Pathways; PBL Netherlands Environmental Assessment Agency: The Hague, The Netherlands, 2016.

129. European Commission. The Land Use Change Impact of Biofuels Consumed in the EU Quantification of Area and Greenhouse Gas Impacts; European Commission: Utrecht, The Netherlands, 2015.

130. European Commission. Positions, Recommendations and Key Messages from the Industry; European Commission: Luxembourg, 2017.

131. Bitnere, K.; Searle, S. Effective Policy Design for Promoting Investment in Advanced Alternative Fuels; International Council on Clean Transportation: Washington, DC, USA, 2017.

132. European Biogas Association. Biomethane in Transport; European Biogas Association: Brussels, Belgium, 2016.

133. JRC; EUCAR; CONCAWE. BioGrace Excel Tool version 4d. In Harmonised Calculations of Biofuel Greenhouse Gas Emissions in Europe; BioGrace: Brussels, Belgium, 2015.

134. Hamelinck, C.; Hoogwijk, M. Future Scenarios of First and Second Generation Biofuels; Ecofys MNP: Utrecht, The Netherlands, 2007.

135. Tonini, D.; Hamelin, L.; Alvarado-Morales, M.; Astrup, T.F. GHG emission factors for bioelectricity, biomethane, and bioethanol quantified for 24 biomass substrates with consequential life-cycle assessment. Bioresour. Technol. 2016, 208, 123-133. [CrossRef] [PubMed]

136. European Commission. Reporting Requirements on Biofuels and Bioliquids Stemming from the Directive (EU) 2015/1513; European Commission: Brussels, Belgium, 2017. 
137. European Commission. Estimates of Indirect Land Use Change from Biofuels Based on Historical Data; JRC Science and Policy Reports: Ispra, Italy, 2015.

138. Rulli, M.C.; Bellomi, D.; Cazzoli, A.; De Carolis, G.; D'Odorico, P. The Water-Land-Food Nexus of First-Generation Biofuels. Sci. Rep. 2016, 6, 22521. [CrossRef] [PubMed]

139. UK Department for Transport. Renewable Transport Fuel Obligation Statistics: Period 10 (2017/18); UK Department for Transport: London, UK, 2019.

140. Mathioudakis, V.; Gerbens-Leenes, P.W.; Van der Meer, T.H.; Hoekstra, A.Y. The water footprint of second-generation bioenergy: A comparison of biomass feedstocks and conversion techniques. J. Clean. Prod. 2017, 148, 571-582. [CrossRef]

141. Immerzeel, D.J.; Verweij, P.A.; Van der Hilst, F.; Faaij, A.P.C. Biodiversity impacts of bioenergy crop production; a state-of-the-art review. Glob. Chang. Biol. Bioenergy 2014, 6, 183-209. [CrossRef]

142. Kline, K.L.; Martinelli, F.S.; Mayer, A.L.; Medeiros, R.; Oliveira, C.O.F.; Sparovek, G.; Walter, A.; Venier, L.A. Bioenergy and Biodiversity: Key Lessons from the Pan American Region. Environ. Manag. 2015, 56, 1377-1396. [CrossRef]

143. Selbmann, K.; Pforte, L. Evaluation of Ecological Criteria of Biofuel Certification in Germany. Sustainability 2016, 8, 936. [CrossRef]

144. Su, Y.; Zhang, P.; Su, Y. An overview of biofuels policies and industrialization in the major biofuel producing countries. Renew. Sustain. Energy Rev. 2015, 50, 991-1003. [CrossRef]

145. Ministry of Energy (PL). Interim Report on Progress in the Promotion and Use of Energy from Renewable Sources in Poland in 2015-2016; Ministry of Energy Poland: Warsaw, Poland, 2018.

146. The Netherlands Enterprise Agency. Progress report. In Energy from Renewable Sources in The Netherlands 2015-2016; The Netherlands Enterprise Agency: Utrecht, The Netherlands, 2017.

147. McGrath, M. Italy Pushes Ahead with 'Next Generation' Biofuels from Waste. 2014. Available online: https://www.bbc.com/news/science-environment-29618889 (accessed on 27 May 2019).

148. Ministry of Energy (RO). Romania's Progress Report on Promoting and Using Energy from Renewable Sources, in Compliance with Article 22 of Directive 2009/28/EC. Available online: https://www.eurobserv-er. org/pdf/res-policy/EurObservER-RES-Policy-Report-Article-22-Romania-report-EN.pdf (accessed on 27 August 2019).

149. Ecofys. Technical Assistance in Realisation of the 2018 Report on Biofuels Sustainability: Biofuels, Biomass $\mathcal{E}$ Biogas Used for Renewable Energy Generation; Ecofys: Utrecht, The Netherlands, 2019.

150. Krukowska, E. EU Sets Limits on Palm Oil in Biofuels as Trade War Looms. 2019. Available online: https://www.bloomberg.com/news/articles/2019-03-13/eu-trying-to-go-green-and-avoid-trade-warwith-palm-oil-giants (accessed on 27 May 2019).

151. Beckman, J. Biofuel Use in International Markets: The Importance of Trade; U.S. Department of Agriculture, Economic Research Service: Washington, DC, USA, 2015. 